American J. of Engineering and Applied Sciences 1 (3): 192-199, 2008

ISSN 1941-7020

(C) 2008 Science Publications

\title{
Strength Modeling of Reinforced Concrete Beam with Externally Bonded Fibre Reinforcement Polymer Reinforcement
}

\author{
${ }^{1}$ N. Pannirselvam, ${ }^{2}$ P.N. Raghunath and ${ }^{2}$ K.Suguna \\ ${ }^{1}$ VIT University, Vellore, India \\ ${ }^{2}$ Department of Civil and Structural Engineering, Annamalai University, Annamalainagar, India
}

\begin{abstract}
This research study presents the evaluation of the structural behaviour of reinforced concrete beams with externally bonded Fibre Reinforced Polymer (FRP) reinforcements. Three different steel ratios with two different Glass Fibre Reinforced Polymer (GFRP) types and two different thicknesses in each type of GFRP were used. Totally fifteen rectangular beams of $3 \mathrm{~m}$ length were cast. Three rectangular beams were used as reference beam (Control Beams) and the remaining were fixed with GFRP laminates on the soffit of the rectangular beam. The variables considered for the study includes longitudinal steel ratio, type of GFRP laminates, thickness of GFRP laminates and composite ratios. Flexural test, using simple beam with two-point loading was adopted to study the performance of FRP plated beams interms flexural strength, deflection, ductility and was compared with the unplated beams. The test results show that the beams strengthened with GFRP laminates exhibit better performance. The flexural strength and ductility increase with increase in thickness of GFRP plate. The increase in first crack loads was up to $88.89 \%$ for $3 \mathrm{~mm}$ thick Woven Rovings GFRP plates and $100.00 \%$ for $5 \mathrm{~mm}$ WRGFRP plated beams and increase in ductility interms of energy and deflection was found to be 56.01 and $64.69 \%$ respectively with $5 \mathrm{~mm}$ thick GFRP plated beam. Strength models were developed for predicting the flexural strength (ultimate load, service load) and ductility of FRP beams. The strength model developed give prediction matching the measurements.
\end{abstract}

Key words: CSMGFRP, FRP, GFRP, steel, strength, WRGFRP

\section{INTRODUCTION}

Fibre Reinforced Polymer (FRP) composite materials have been successfully used in new construction and for rehabilitation of existing structures. FRP composite materials hold great promise for the future of construction industry. Strengthening of reinforced concrete and prestressed concrete structures may be required as a result of increase in service loads, change in usage pattern, structural degradation and defects in design or construction. Repair with externally bonded FRP reinforcement is a highly practical strengthening system, because of ease and speed of installation, efficiency of the structural repair and corrosion resistance of the materials. The application of FRP poses minimal modification to the geometry, aesthetics and utility of the structure. Several studies on the behavior of reinforced concrete beams strengthened with FRP composite sheets provided valuable information regarding the strength, deformation, ductility and long-term performance of the FRP strengthening systems. Installation of externally bonded upgradation systems using FRP is fast and less labour intensive. Tension delamination of concrete cover in midspan of FRP strengthened beams by combining Carbon Fibre Reinforced Polymer sheets (CFRP) and Glass Fibre Reinforced Polymer sheet (GFRP) sheets at midspan of a beam and wrapped on 3 sides of the beam continuously with unidirectional CFRP on the tension of the beams and bi-directional GFRP sheet ${ }^{[1,2]}$. The flexural strengthening of reinforced concrete continuous beams with different arrangements of internal steel bars and external CFRP laminates are used for estimating the flexural load capacity and the interface shear stresses between the adhesive and concrete at failure of beams ${ }^{[3]}$. The effectiveness of the epoxy bonding of CFRP sheets to the tension flange of steel-concrete composite girders was analyzed using an iterative numerical method ${ }^{[4]}$. The shear strength of GFRP reinforced concrete beams and slabs were verified by the shear design approach and limits were proposed by ACI committee $440 \mathrm{H}^{[5,6]}$. The strengthening of corrosion damaged reinforced concrete bridge girders beams were strengthened by externally

Corresponding Author: N. Pannirselvam, Senior Lecturer, VIT University, Vellore, India 
Am. J. Engg. \& Applied Sci., 1 (3): 192-199, 2008

Table 1: Specimen specification

\begin{tabular}{llllll}
\hline S. No. & Beam designation & \% Steel reinforcement & Type of GFRP & Thickness of GFRP & $\begin{array}{l}\text { Composite Ratio } \\
\text { (Area of FRP / Area of Steel) }\end{array}$ \\
\hline 1. & SR1 & 0.419 & - & - & - \\
2. & SR1CSM3 & 0.419 & CSM & 3 & 2.387 \\
3. & SR1CSM5 & 0.419 & CSM & 5 & 3.979 \\
4. & SR1WR3 & 0.419 & WR & 3 & 2.387 \\
5. & SR1WR5 & 0.419 & WR & 5 & -979 \\
6. & SR2 & 0.603 & - & - & 1.562 \\
7. & SR2CSM3 & 0.603 & CSM & 3 & 2.653 \\
8. & SR2CSM5 & 0.603 & CSM & 5 & 1.592 \\
9. & SR2WR3 & 0.603 & WR & 3 & - \\
10. & SR2WR5 & 0.603 & - & 5 & 1.231 \\
11. & SR3 & 0.905 & WR & - & 2.051 \\
12. & SR3CSM3 & 0.905 & CSM & 3 & 1.231 \\
13. & SR3CSM5 & 0.905 & WR & 5 & 2.051 \\
14. & SR3WR3 & 0.905 & WR & 3 & 5 \\
15. & SR3WR5 & 0.905 & & & \\
\hline
\end{tabular}

Note: CSM-Chopped Strand Mat; WR-Woven Rovings

epoxy bonding CFRP laminates to the concrete surface $^{[7]}$. By increasing the flexural performance of $\mathrm{RC}$ beams strengthened with CFRP materials was studied $^{[8]}$ and the results indicated substantial improvements in strength.

Test plan: Experimental investigation was carried out on fifteen beam specimens having three steel ratios, wrap thicknesses and wrap materials. Manual readings were recorded directly into a spreadsheet program for easy processing. The specimens were tested under fourpoint bending. Sufficient data was obtained on the strength, deformation and failure characteristics of GFRP laminated as well as control beams. The details of the fifteen specimens prepared for experimental work are shown in Table 1.

\section{MATERIALS AND METHODS}

M20 grade concrete was used for casting the specimens. The designed mix proportion was 1:1.54: 3.01 with water cement ratio of 0.5 . Fine aggregates passing through $4.75 \mathrm{~mm}$ IS sieve and coarse aggregates passing through $20 \mathrm{~mm}$ IS sieves were used for concreting. The compressive strength of cubes tested after 28 days was $23.54 \mathrm{MPa}$. Glass fibre types such as Chopped Strand Mat and Woven Rovings were used for this investigation. The properties of GFRP laminates and epoxy adhesives used for the investigation are shown in Table 2.

Preparation of specimens: A tilting type drawn mixer was used for mixing fresh concrete. The cement, sand and coarse aggregate were placed inside the wet drawn and then dry mixed. Concrete was placed in three layers up to the top of rectangular beam and compacted.
Table 2: Characteristic Properties of GFRP laminates and Epoxy Adhesives as per ASTM D 638

\begin{tabular}{llll}
\hline S. No. & Property & $\begin{array}{l}\text { Test value } \\
\text { of GFRP }\end{array}$ & $\begin{array}{l}\text { Test value } \\
\text { of epoxy }\end{array}$ \\
\hline 1 & Tensile strength at break (MPa) & 77.30 & 2.80 \\
2 & Elongation at break (\%) & 6.00 & 16.00 \\
3 & Elasticity modulus (MPa) & 2600.00 & 14.60 \\
4 & Tensile strength at yield (MPa) & 80.80 & 3.50 \\
5 & Shear strength (MPa) & 75.20 & 6.00 \\
6 & Flexural strength (MPa) & 11.60 & 0.32 \\
7 & Compressive strength (MPa) & 190.00 & 10.5 \\
\hline
\end{tabular}

Curing was carried for a period of 28 days. The soffit of the rectangular beam was well cleaned with a wire brush and roughened with a surface-grinding machine. Two part epoxy adhesive consisting of epoxy resin and silica filler was used to paste the FRP laminates. The glue was spread over the pasting surface with the help of a spreads. A thickness of more than $2 \mathrm{~mm}$ was maintained throughout the length of the pasting area. The laminate was pasted by gently pressing it by hand from one end and solely moving toward the other end. A nominal weight to keep in position was placed over the laminates. The oozing out compound was removed. The final thickness of the glue will be around $2 \mathrm{~mm}$ thick. The beam is left undisturbed for one week and then subjected to testing.

Test procedure: The beams were tested under twopoint loading after curing for 28 days at room temperature. Before testing, the beams were painted white and centre line of the beam in the longitudinal direction was marked to study the crack patterns during testing. All the beams were tested in a loading frame of $750 \mathrm{KN}$ capacities and $100 \mathrm{~mm}$ bearing was given on both ends, resulting in a effective test span of $2800 \mathrm{~mm}$ as shown in Fig. 1. 


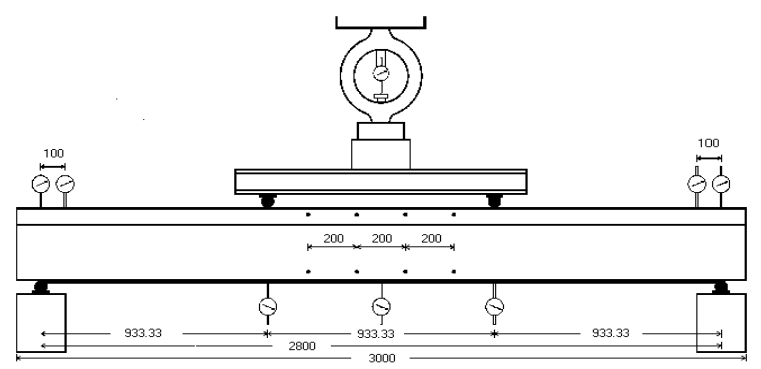

Fig. 1: Details of test beam

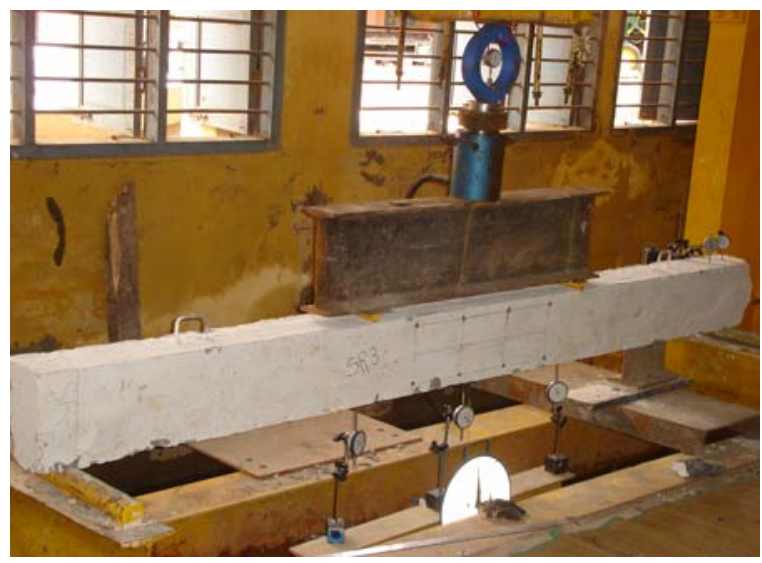

Fig. 2: Test setup

The deflections were measured at midspan and load points using mechanical dial gauges of $0.01 \mathrm{~mm}$ accuracy. The crack widths were measured using a crack defection microscope with a least count of $0.02 \mathrm{~mm}$. The deflections and crack width were measured at different load levels until failure. The details of test setup are shown in Fig. 2.

\section{RESULTS AND DISCUSSION}

Table 3 and Fig. 3-10 show the test results of GFRP beam. The effect of steel ratio on any property was evaluated by comparing the performance levels of beams with steel ratio $0.603 \%$ and $0.905 \%$ against the beam with steel ratio of $0.419 \%$. The effect of thickness of GFRP plate on performance parameters was measured by comparing the performance of plated beam with that of unplated beam having the same steel ratio. For ascertaining the effect of type of fibre on the performance of beams, comparison was made between CSM and WR plated beams of similar thickness plating. The radius of curvature values were deduced from mid-span deflection using a simple relationship between mid-span deflection and curvature at mid-span.

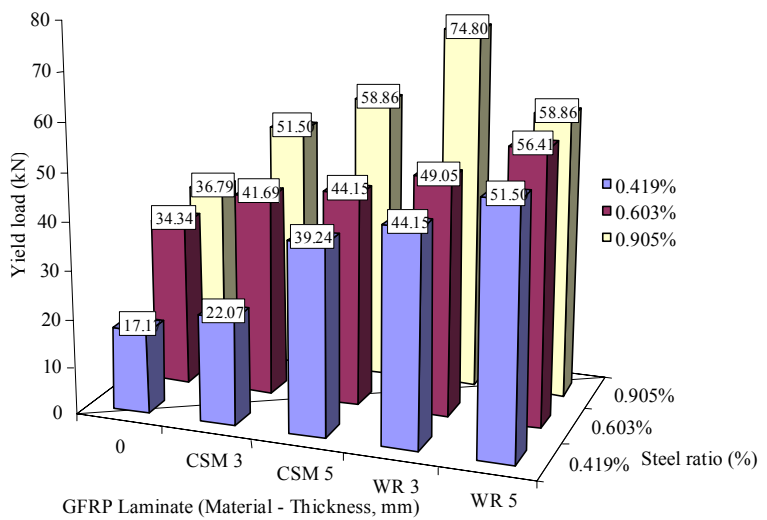

Fig. 3: Yield load

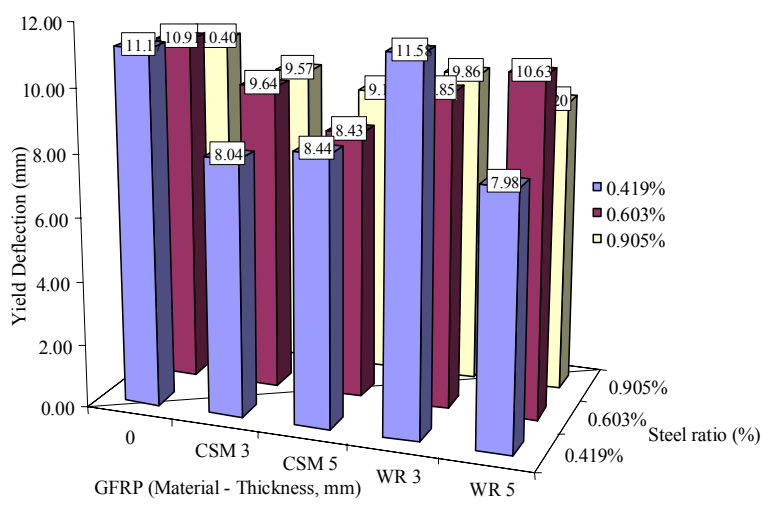

Fig. 4: Yield deflection

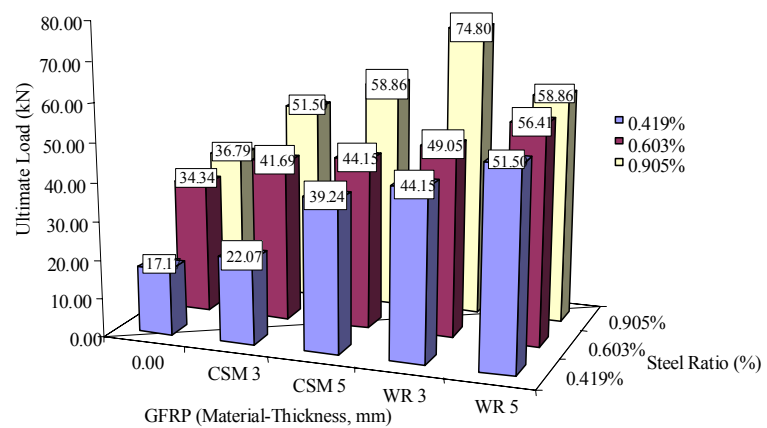

Fig. 5: Ultimate load

The data used for the regression analysis is shown in Table 3 and the regression equations are shown in Table 4.

Observations on the regression equations: The regression equations were used for predicting the ultimate load and ultimate deflection values. An observation of the measures of fitness of regression 


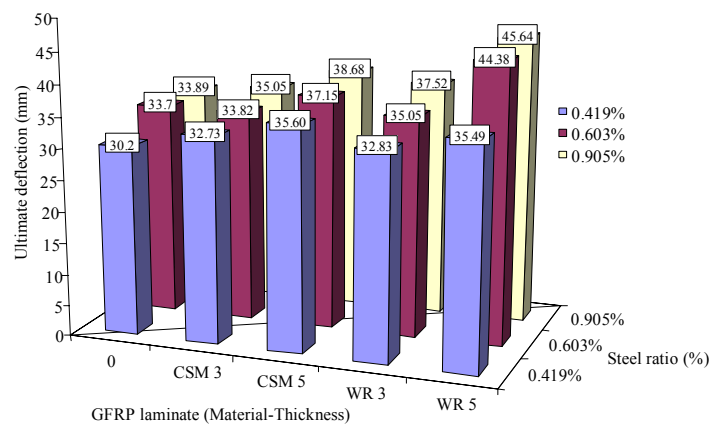

Fig. 6: Ultimate deflection

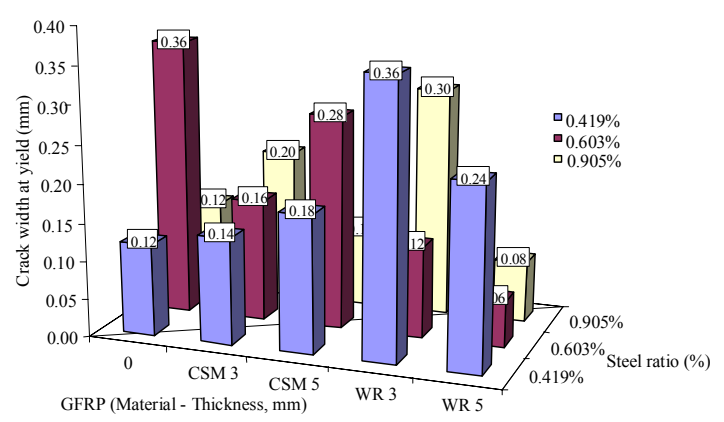

Fig. 7: Crack width values at yield point

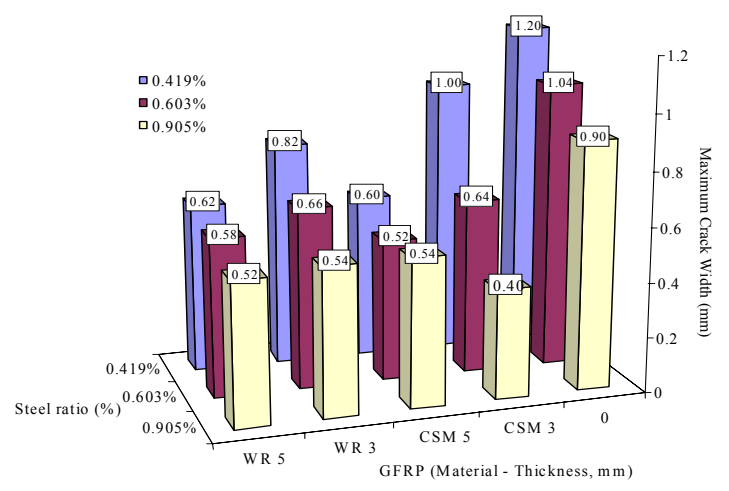

Fig. 8: Crack width at ultimate load

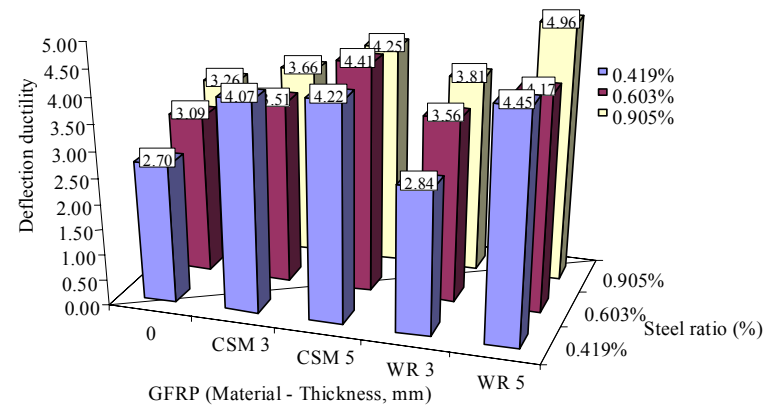

Fig. 9: Deflection ductility

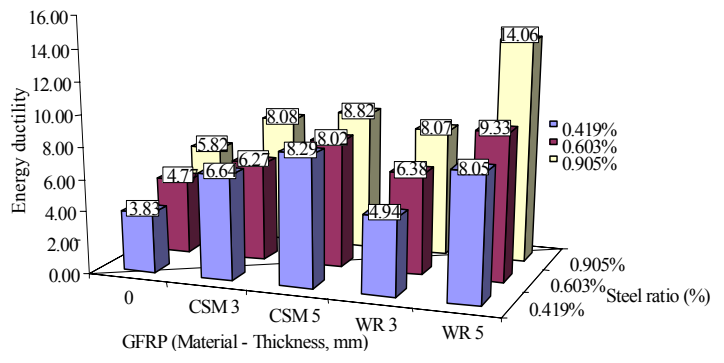

Fig. 10: Energy ductility

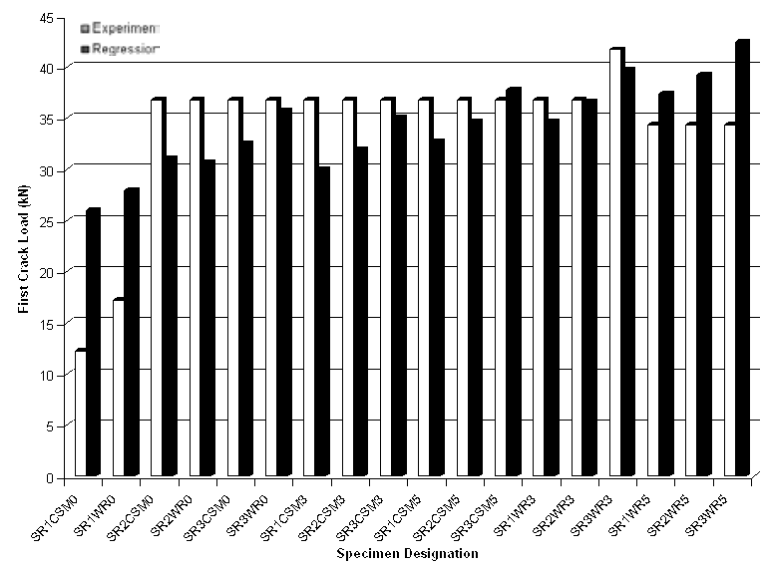

Fig. 11: Regression predictions for first crack load

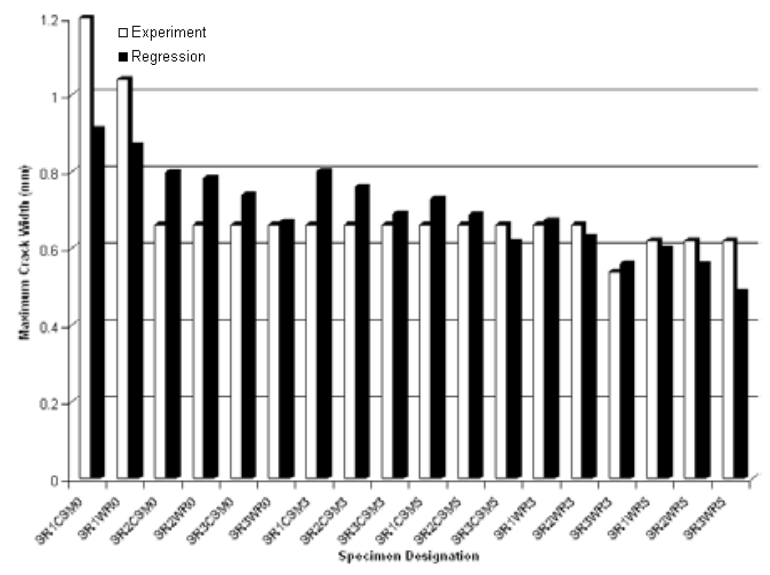

Fig. 12: Regression predictions for first crack deflection

shows that the multivariate linear regression can estimate the prediction values with reasonable levels of accuracy for ultimate stress, deflection ductility, energy ductility and total energy absorption. Linear regressions are inherently limited in their ability to model very complex sets of data, since first order regression parameters try to fit a monotonically varying linear 
Am. J. Engg. \& Applied Sci., 1 (3): 192-199, 2008

Table 3: Data used for regression analysis

\begin{tabular}{|c|c|c|c|c|c|c|c|c|c|c|c|c|c|c|c|c|c|c|}
\hline Designation & $\begin{array}{l}\text { SR1 } \\
\text { CSM0 }\end{array}$ & $\begin{array}{l}\text { SR2 } \\
\text { CSM0 }\end{array}$ & $\begin{array}{c}\text { SR3 } \\
\text { 0CSM0 }\end{array}$ & $\begin{array}{l}\text { SR1 } \\
\text { WR0 }\end{array}$ & $\begin{array}{l}\text { SR2 } \\
\text { WR0 }\end{array}$ & $\begin{array}{l}\text { SR3 } \\
\text { WR0 }\end{array}$ & $\begin{array}{l}\text { SR1 } \\
\text { CSM3 }\end{array}$ & $\begin{array}{l}\text { SR2 } \\
\text { CSM3 }\end{array}$ & $\begin{array}{l}\text { SR3 } \\
\text { CSM3 }\end{array}$ & $\begin{array}{l}\text { SR1 } \\
\text { CSM5 }\end{array}$ & $\begin{array}{l}\text { SR2 } \\
\text { CSM5 }\end{array}$ & $\begin{array}{c}\text { SR3 } \\
\text { 5CSM5 }\end{array}$ & $\begin{array}{l}\text { SR1 } \\
5 \text { WR3 }\end{array}$ & $\begin{array}{l}\text { SR2 } \\
\text { WR3 }\end{array}$ & $\begin{array}{l}\text { SR3 } \\
\text { WR3 }\end{array}$ & $\begin{array}{l}\text { SR1 } \\
\text { WR5 }\end{array}$ & $\begin{array}{l}\text { SR2 } \\
\text { WR5 }\end{array}$ & $\begin{array}{l}\text { SR3 } \\
\text { WR5 }\end{array}$ \\
\hline $\begin{array}{l}\text { irst crack } \\
\text { oad }(\mathrm{kN})\end{array}$ & 12.26 & 17.17 & 36.79 & 12.26 & 17.17 & 36.79 & 36.79 & 36.79 & 36.79 & 36.79 & 36.79 & 36.79 & 36.79 & 36.79 & 41.69 & 34.34 & 34.34 & 34.34 \\
\hline $\begin{array}{l}\text { rst crack } \\
\text { flection }(\mathrm{mm})\end{array}$ & 1.57 & 3.29 & 6.32 & 1.57 & 3.29 & 6.32 & 6.32 & 6.32 & 6.32 & 6.32 & 6.32 & 6.32 & 6.32 & 6.32 & 7.47 & 8.39 & 8.39 & 8.39 \\
\hline rvice load $(\mathrm{kN})$ & 2.89 & 7.79 & 42.51 & 22.89 & 27.79 & 42.51 & 24.53 & 35.97 & 44.15 & 32.70 & 40.87 & 53.95 & 39.24 & 49.05 & 52.32 & 242.51 & 58.86 & 70.31 \\
\hline ) & 1.57 & 2.55 & 2.97 & 1.57 & 2.55 & 2.97 & 2.97 & 2.97 & 2.97 & 2.97 & 2.97 & 2.97 & 2.97 & 2.97 & 4.72 & 3.19 & 3.19 & 3.19 \\
\hline CO & 7.17 & 4.34 & 49.05 & 7.17 & 4.34 & 49.05 & 49.05 & 49.05 & 49.05 & 49.05 & 49.05 & 49.05 & 49.05 & 49.05 & 74.80 & 51.50 & 51.50 & 51.50 \\
\hline$(\mathrm{mm})$ & 11.17 & 0.91 & 9.85 & 1.17 & 10.91 & 9.85 & 9.85 & 9.85 & 9.85 & 9.85 & 9.85 & 9.85 & 9.85 & 9.85 & 9.86 & 7.98 & 7.98 & 7.98 \\
\hline Crack width & 0.12 & 0.36 & 0.12 & 0.12 & 0.36 & 0.12 & 0.12 & 0.12 & 0.12 & 0.12 & 0.12 & 0.12 & 0.12 & 0.12 & 0.30 & 0.24 & 0.24 & 0.24 \\
\hline load (kN) & 4.34 & .69 & .58 & .34 & & 73 & & 73.58 & 73. & 73.58 & 73.58 & 73 & 73.58 & 73.58 & 78.48 & 363. & 63.77 & 63.77 \\
\hline (n) & 30.20 & 33.70 & 35.05 & 0.20 & 33.70 & 35.05 & & 35.05 & 35.05 & 35.05 & 35.05 & 35.05 & 35.05 & 35.05 & 37.2 & 236.49 & 36.49 & 36.4 \\
\hline Maximun & 1.20 & 1.04 & 0.66 & 1.20 & 1.04 & 0.66 & 0.66 & 0.66 & 0.66 & 0.66 & 0.66 & 0.66 & 0.66 & 0.66 & 0.54 & 0.62 & 0.62 & 0.62 \\
\hline & 2.70 & & & & & & & & & & & & & & & . & 5 & 4.45 \\
\hline & 3.83 & 4.77 & & 3.83 & & & & & & & 6.38 & 6.3 & 6.38 & & 8.07 & 8.05 & 55 & 8.05 \\
\hline Deflection & 1.00 & 1.00 & 1.15 & 1.00 & 1.00 & 1.15 & 1.15 & 1.15 & 1.15 & 1.15 & 1.15 & 1.15 & 1.15 & 1.15 & 1.17 & 1.64 & 1.64 & 1.64 \\
\hline $\begin{array}{l}\text { Energy ductility } \\
\text { Ratio }\end{array}$ & 1.00 & 1.00 & 1.34 & 1.00 & 1.00 & 1.34 & 1.34 & 1.34 & 1.34 & 1.34 & 1.34 & 1.34 & 1.34 & 1.34 & 1.39 & 2.10 & 2.10 & 2.10 \\
\hline
\end{tabular}

Table 4: Regression equations

\begin{tabular}{|c|c|c|c|c|}
\hline Sl. No. & Prediction Parameter & Equation & Fitness & RMS Error \\
\hline 1 & First crack load $(\mathrm{kN})$ & $16.9610 .4319 \mathrm{R}_{\mathrm{S}}+4.6333 \mathrm{~F}_{\mathrm{t}}+1.3450 \mathrm{t}_{\mathrm{f}}$ & 0.344 & 5.75 \\
\hline 2 & First crack deflection (mm) & $1.206+2.0513 \mathrm{R}_{\mathrm{S}}+1.6822 \mathrm{~F}_{\mathrm{t}}+0.4687 \mathrm{t}_{\mathrm{f}}$ & 0.71 & 0.86 \\
\hline 3 & Service load $(\mathrm{kN})$ & $15.39+5.2144 \mathrm{R}_{\mathrm{S}}+1.7256 \mathrm{~F}_{\mathrm{t}}+0.5379 \mathrm{t}_{\mathrm{f}}$ & 0.21 & 3.39 \\
\hline 4 & Service deflection (mm) & $1.352+1.0918 \mathrm{R}_{\mathrm{S}}+0.4700 \mathrm{~F}_{\mathrm{t}}+0.0918 \mathrm{t}_{\mathrm{f}}$ & 0.47 & 0.40 \\
\hline 5 & Yield load $(\mathrm{kN})$ & $16.9+20.0165 \mathrm{R}_{\mathrm{S}}+8.8544 \mathrm{~F}_{\mathrm{t}}+1.9733 \mathrm{t}_{\mathrm{f}}$ & 0.49 & 7.32 \\
\hline 6 & Yield deflection (mm) & $11.98-0.4621 \mathrm{R}_{\mathrm{S}}-0.8867 \mathrm{~F}_{\mathrm{t}}-0.2557 \mathrm{t}_{\mathrm{f}}$ & 0.68 & 0.48 \\
\hline 7 & Crack width at yield load (mm) & $0.07057+0.0524 \mathrm{R}_{\mathrm{S}}+0.0333 \mathrm{~F}_{\mathrm{t}}+0.0034 \mathrm{t}_{\mathrm{f}}$ & 0.79 & 0.071 \\
\hline \multirow[t]{2}{*}{8} & Ultimate load $(\mathrm{kN})$ & $P_{u}=\kappa\left(2.75 \mathrm{~A}_{\mathrm{s}} \mathrm{f}_{\mathrm{s}}\left(\mathrm{d}-\frac{\beta_{1} \mathrm{c}}{2}\right)+1.7 \mathrm{~A}_{\mathrm{f}} \mathrm{f}_{\mathrm{f}}\left(\mathrm{h}-\frac{\beta_{1} \mathrm{c}}{2}\right)-106\right)$ & 0.61 & 11.9 \\
\hline & & where $\kappa$ is a constant with value of $6 / 2.8 \times 10^{6}$ ) & & \\
\hline 9 & Ultimate deflection $(\mathrm{mm})$ & $30.37+2.4706 \mathrm{R}_{\mathrm{S}}+1.4433 \mathrm{~F}_{\mathrm{t}} 0.3610 \mathrm{t}_{\mathrm{f}}$ & 0.63 & 0.88 \\
\hline 10 & Maximum crack width (mm) & $1.137-0.2312 \mathrm{R}_{\mathrm{S}}-0.1289 \mathrm{~F}_{\mathrm{t}}-0.0365 \mathrm{t}_{\mathrm{f}}$ & 0.50 & 0.11 \\
\hline 11 & Deflection ductility & $2.348+0.3823 \mathrm{R}_{\mathrm{S}}+0.4722 \mathrm{~F}_{\mathrm{t}} 0.1297 \mathrm{t}_{\mathrm{f}}$ & 0.73 & 0.22 \\
\hline 12 & Energy ductility & $2.935+1.4903 \mathrm{R}_{\mathrm{S}}+1.2067 \mathrm{~F}_{\mathrm{t}}+0.3072 \mathrm{t}_{\mathrm{f}}$ & 0.77 & 0.51 \\
\hline 13 & Deflection ductility ratio & $0.7294+0.0618 \mathrm{R}_{\mathrm{S}}+0.1989 \mathrm{~F}_{\mathrm{t}}+0.1557 \mathrm{t}_{\mathrm{f}}$ & 0.61 & 0.12 \\
\hline 14 & Energy ductility ratio & $0.5881+0.1418 \mathrm{R}_{\mathrm{S}}+0.3344 \mathrm{~F}_{\mathrm{t}}+0.0941 \mathrm{t}_{\mathrm{f}}$ & 0.66 & 0.19 \\
\hline
\end{tabular}

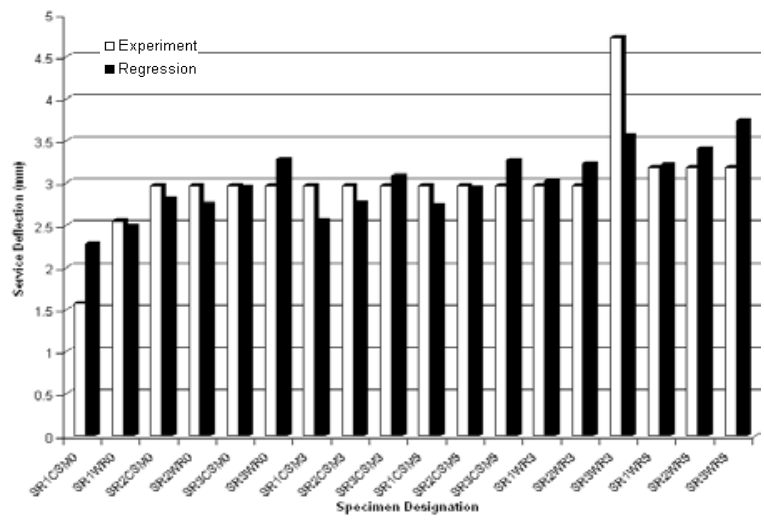

Fig. 13: Regression predictions for service deflection

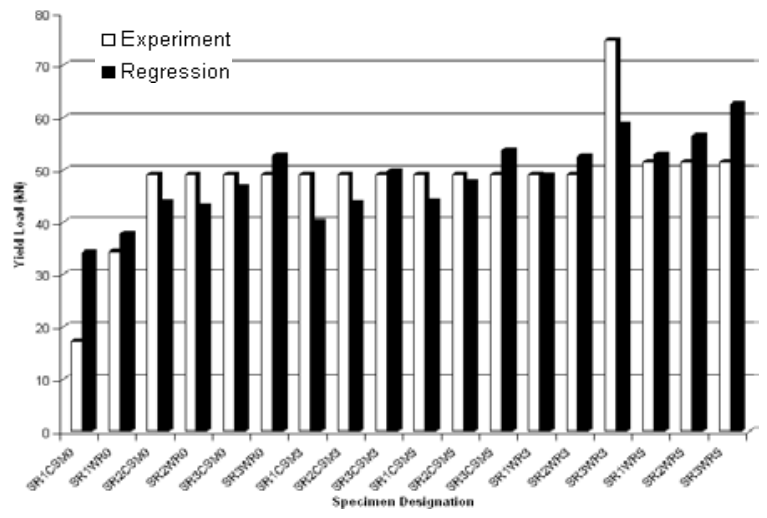

Fig. 14: Regression predictions for yield load 


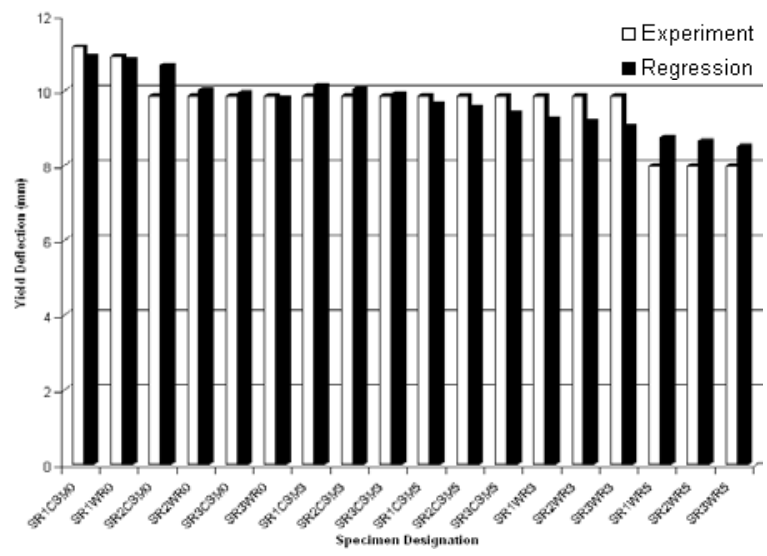

Fig. 15: Regression predictions for yield deflection

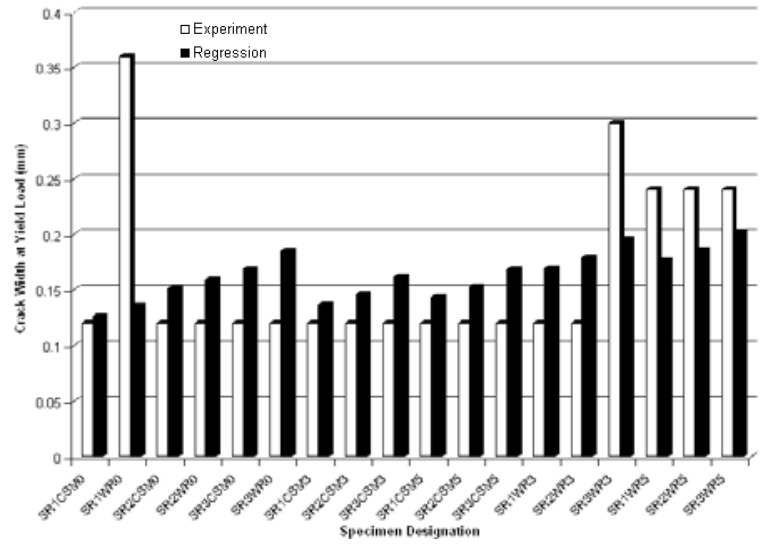

Fig. 16: Regression predictions for crack width at yield load

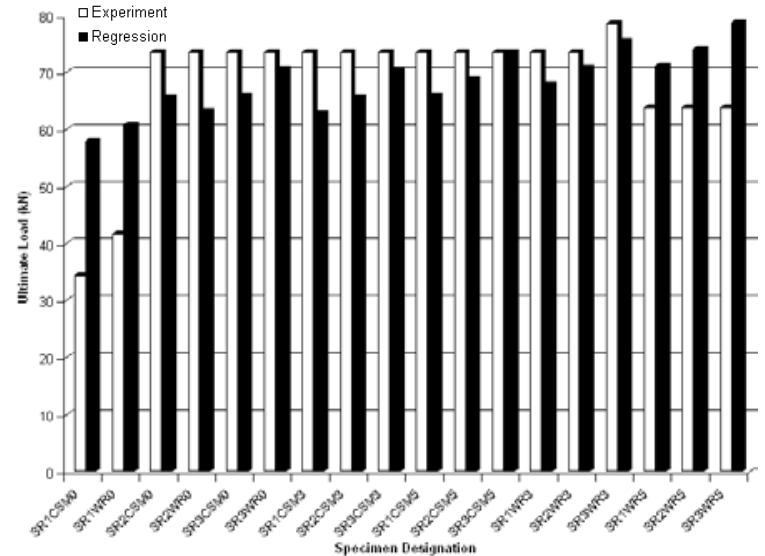

Fig. 17: Regression predictions for ultimate load

relationship curvature for the prediction parameter. In spite of the apparently larger errors, regression

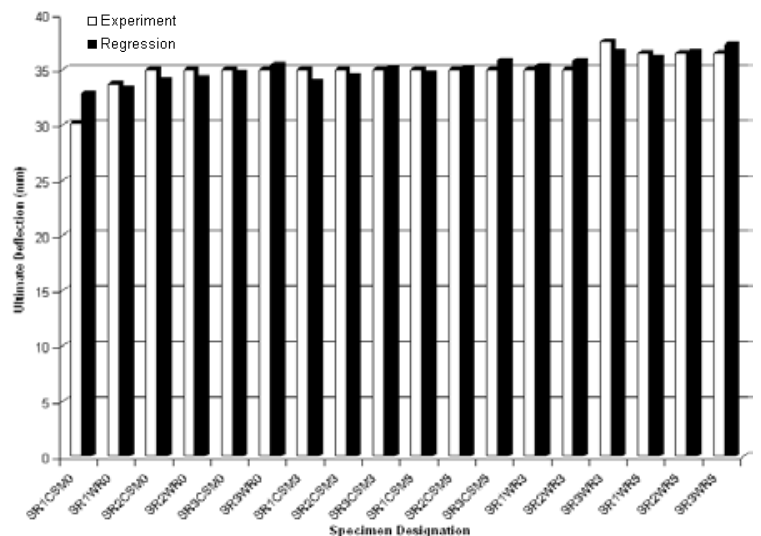

Fig. 18: Regression predictions for ultimate deflection

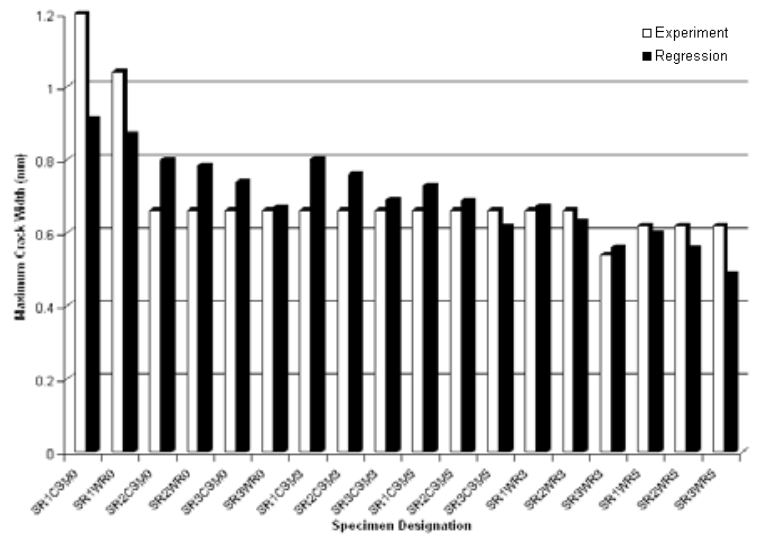

Fig. 19: Regression predictions for maximum crack width

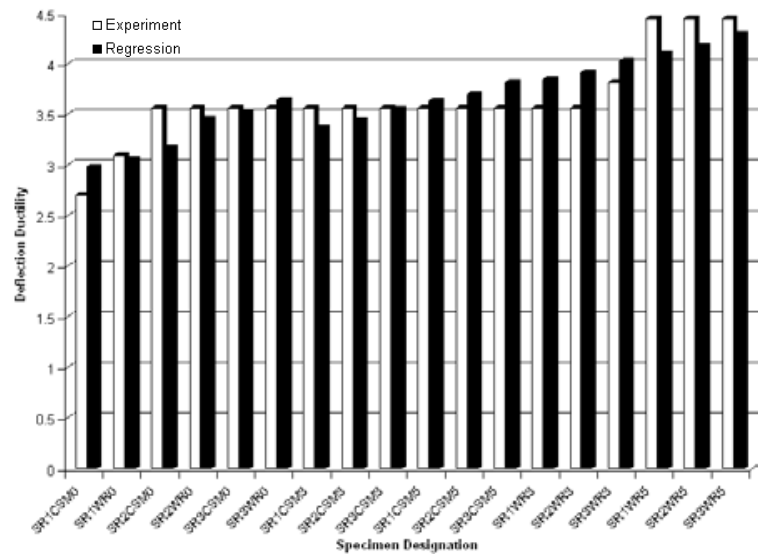

Fig. 20: Regression predictions for deflection ductility

equations are useful for estimating the values of parameters when no sophisticated computational tool is 


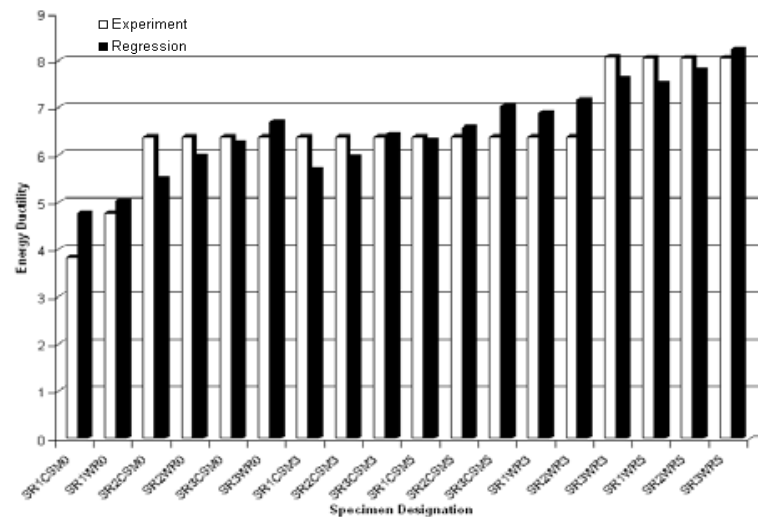

Fig. 21: Regression predictions for energy ductility

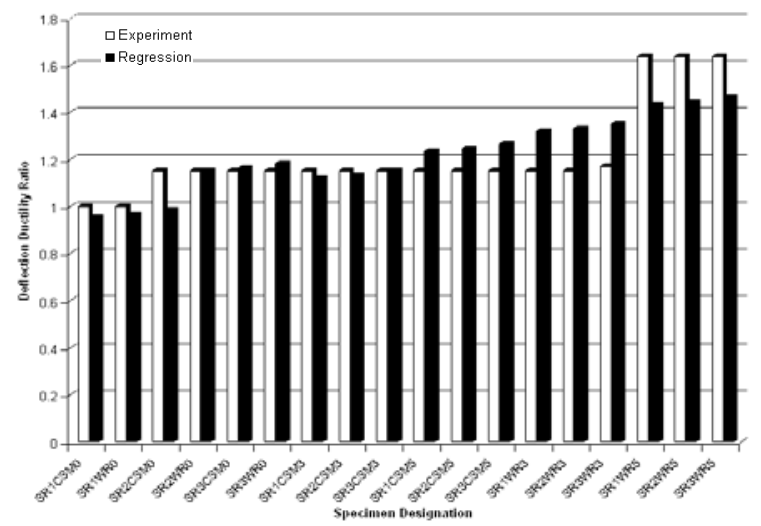

Fig. 22: Regression predictions for deflection ductility ratio

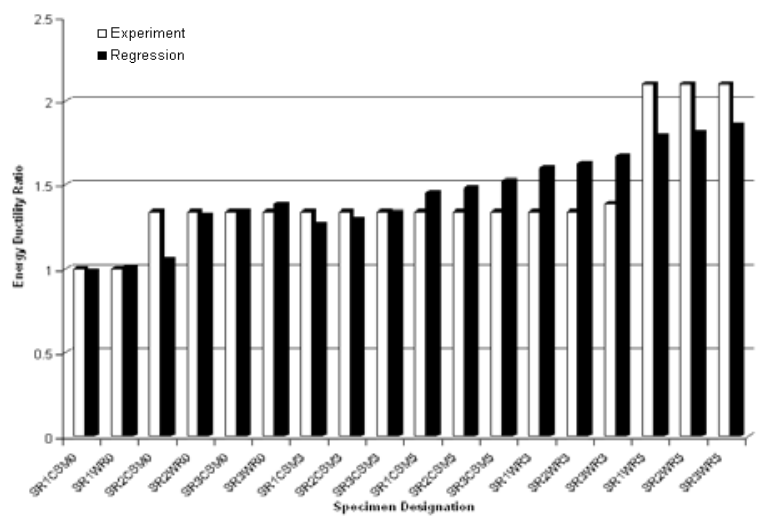

Fig. 23: Regression predictions for energy ductility ratio

available. Predictions from the regression equations were compared against experimental values and presented in Fig. 11-23.

\section{CONCLUSIONS}

- Strengthening of reinforced concrete beams using GFRP plates resulted in higher load carrying capacity for beams. The WRGFRP plating showed higher improvement in first crack load, while the CSMGFRP showed limited enhancement in first crack load. The increase in first crack loads was up to $88.89 \%$ for $3 \mathrm{~mm}$ thick WRGFRP plates and $100.00 \%$ for $5 \mathrm{~mm}$ WRGFRP plated beams

- The deflections at which first cracks appeared at the tension zone of the beams were higher for GFRP plated beams. The maximum reductions in first crack load were up to $50.59 \%$ for $3 \mathrm{~mm}$ thick plating and up to $58.59 \%$ for $5 \mathrm{~mm}$ thick plating.

- Yield loads increased substantially due to the bonding of GFRP plates. The increase level of achieved by WRGFRP plates was higher than those achieved by CSMGFRP plates. The increase in yield load was up to $40.00 \%$ for $3 \mathrm{~mm}$ thick CSMGFRP and $128.57 \%$ for $5 \mathrm{~mm}$ CSMGFRP, $103.33 \%$ for $3 \mathrm{~mm}$ WRGFRP and $200.00 \%$ for 5 mm WRGFRP plating

- Yield deflection values were marginally lower for GFRP plated beams compared to the unplated beams. The reduction in yield deflection ranged from $7.99-28.03 \%$ for $3 \mathrm{~mm}$ GFRP plated beams and from $5.19 \%$ to $28.54 \%$ for $5 \mathrm{~mm}$ GFRP plated beams

- The increase in ultimate load ranged from 28.57$40.00 \%$ for $3 \mathrm{~mm}$ CSMGFRP and $28.57-128.57 \%$ for $5 \mathrm{~mm}$ CSMGFRP plating

- WRGFRP plating resulted in substantially higher ultimate load levels compared to CSMGFRP plating. Increase of ultimate strength ranged from $42.86-103.33 \%$ for $3 \mathrm{~mm}$ WRGFRP plating and from $60.00-200.00 \%$ for $5 \mathrm{~mm}$ WRGFRP plating

- The increase in deflection ductility ranged from $30.30-56.01 \%$ with $5 \mathrm{~mm}$ CSMGFRP plating and from $35.16-64.69 \%$ with thick $5 \mathrm{~mm}$ for WRGFRP plating

\section{REFERENCES}

1. Taheri, F., K. Shahin and I. Widiarsa, 2002. On the parameters influencing the performance of reinforced concrete beams strengthened with FRP plates. Composite Struct., 58: 217-226. Doi: 10.1016/S0263-8223(02)00120-4.

2. Xiong, G.J., X. Jiang, J.W. Liu and L. Chen, 2007. A way for preventing tension delamination of concrete cover in midspan of FRP strengthened beams. J. Construct. Build. Mater., 21: 402-408. Doi: 10.1016/j.conbuildmat.2005.08.005 
3. Ashour, A.F, S.A. El-Refaie and S.W. Garrity, 2004. Flexural strengthening of RC continuous beams using CFRP laminates. Cement Concr. Composites, 26: 765-775. doi: 10.1016/j. cemconcomp.2003.07.002

4. Tavakkollzadeh, M. and H. Saadatmanesh, 2003. Strengthening of steel-concrete composite girders using carbon fiber reinforced polymer sheets. J. Struct. Eng. ASCE, 129: 30-40 Doi: 10.1061/ (ASCE)0733-9445(2003)129:1(30))

5. Alex, Li, J.A. and Y. Delmas, 2001. Shear strengthening of $\mathrm{RC}$ beams with externally bonded CFRP sheets. J. Struct. Eng. ASCE, 127: 374-380. Doi: 10.1061/(ASCE)0733-9445 (2001)127:4(374)
6. Riyadh, Al-Amery and Riadh Al-Mahaidi, 2006. Coupled flexural-shear retrofitting of RC beams using CFRP straps. Composite Struct., 75: 457-464 Doi:10.1016/j.compstruct.2006.04.037

7. Khaled, A.S. and T.G. Sherwood, 2000. Behaviour of reinforced concrete beams strengthened with carbon fibre reinforced polymer laminates subjected to corrosion damage. Can. J. Civ. Eng. Rev. Can. Genie Civ., 27: 1005-1010. Doi: 10.1139/cjce-27-5-1005

8. Laura, A., B.A. Antonio and F. Giusy 2005. Increasing the flexural performance of RC beams strengthened with CFRP materials. Construct. Build. Mater., 19: 55-61. Doi: 10.1016/j. conbuildmat.2004.04.011 